\title{
Embryonic dormancy in seeds of Bactris gasipaes Kunth (peach-palm) ${ }^{1}$
}

\author{
Patricia Nazário ${ }^{2 *}$, Sidney Alberto do Nascimento Ferreira ${ }^{2}$, \\ Eduardo Euclydes de Lima Borges ${ }^{3}$
}

\begin{abstract}
Bactris gasipaes is a domesticated palm whose fruits are of great importance for the Amazonian people and whose heart of palm is also receiving economic interest in other brazilian and Latin America regions. The aim of this study was verify embryonic dormancy and its correlation with first cataphyll emergence in B. gasipaes seeds collected from four plants at Manaus city and four others at Coari city, both in the Amazonas state, Brazil. After extraction and cleaning, some of the seeds (4 replications of 25 per plant) were sown in a seedbed with a sawdust and sand mixture as substrate, and embryos ( 4 replications of 10 per plant), after extraction, were inoculated into half strength Murashige and Skoog cultures. Were used 100 seeds and 40 embryo per treatment. Whole seed and embryo germination varied between the different source plants and locations, with the greatest difference observed for the emergence of first cataphyll from seeds in the seedbed. For the most part of variables, results of seed and embryo were positively associated, namely, as one went up the other also, and vice versa. These results suggesting that, at least in part, seed dormancy in Bactris gasipaes is associated with embryonic dormancy.
\end{abstract}

Index terms: Arecaceae, embryo, emergence, germination.

\section{Dormência embrionária em sementes de Bactris gasipaes Kunth (pupunha)}

\begin{abstract}
RESUMO - Bactris gasipaes é uma palmeira domesticada com frutos de grande importância para os povos da Amazônia cujo palmito tem tido interesse econômico em outras regiões brasileiras e América Latina. Este estudo objetivou verificar a dormência embrionária e sua correlação com a emergência do primeiro catáfilo em sementes de B. gasipaes coletadas de quatro plantas na cidade de Manaus e quatro na de Coari, Amazonas, Brasil. Após extração e lavagem, algumas das sementes (4 repetições de 25 por planta) foram semeadas em sementeira contendo uma mistura de serragem e areia como substrato, e os embriões (4 repetições de 10 por planta), após a extração, foram inoculados em meio de cultura Murashige e Skoog. Foram utilizadas 100 sementes e 40 embriões por tratamento. A germinação das sementes integrais bem como a germinação de embriões variaram entre as diferentes plantas e procedências, com maior diferença observada para o surgimento do primeiro catáfilo a partir de sementes inteiras. Para a maior parte das variáveis, os resultados foram positivamente associados entre sementes e embriões. Estes resultados sugerem que a dormência em sementes de $B$. gasipaes pode ser atribuída, ao menos em parte, à dormência embrionária.
\end{abstract}

Termos para indexação: Arecaceae, embrião, emergência, germinação.

\section{Introduction}

The genus Bactris constitutes one of the most diversified palm groups in the New World, encompassing around 92 species, and its greatest diversity is found in the Amazon Basin, where at least 30 species are known to occur (Goulding and Smith, 2007; The Plant List, 2013). Of these,

${ }^{1}$ Submitted on 05/05/2016. Accepted for publication on 03/06/2017. ${ }^{2}$ Instituto Nacional de Pesquisas da Amazônia, Caixa Postal 2223, 69080-971 - Manaus, AM, Brasil. the domesticated species B. gasipaes, or peach-palm, is the most widely distributed Bactris palm in Western Amazonia. The species occurs near the sites of ancient villages near the borders of major rivers, and its abundance depends upon its significance to local inhabitants (Clement, 2008).

The reproduction of the peach-palm has been the focus of research for more than a century (Barbosa-Rodrigues, 1899)

${ }^{3}$ Departamento de Engenharia Florestal, UFV, 36570-000 - Viçosa, MG, Brasil. *Corresponding author $<$ pattyinpa78@hotmail.com> 
and, due to increased demand for palm, especially in the last 30 years, has spurred additional studies with the goals of achieving optimal propagation and identifying methods for in situ and ex situ conservation. In the greatest consumers regions of the Brazil, the consume of peach palm cultivated in the market increased from $19.5 \% 2009$ to $24 \%$ in 2010 . Between 2009 and 2011, in Rio de Janeiro, increasing palm consumption was $36 \%$, already the pupunha grew $151 \%$. In São Paulo, which is the State where more is consumed heart of palm in the country, the growth was $20 \%$. In the States of Minas Gerais and Espírito Santo, the palm heart consumption, derived from various palms, increased $42 \%$, while heart of palm consumption grew $480 \%$. In southern Brazil, consumption between the period before cited grown palm, especially pupunha, increased 78\% (Ribeiral, 2011).

The germination capacity of dissimilar seed progenies varies from $0 \%$ to $100 \%$, and the germination process requires 38 to 133 days (Bovi et al., 1994). The seeds also display dormancy for variable durations that range from 2 weeks to 14 months (Mora-Urpí, 1979). To date, the dormancy factors of $B$. gasipaes have not been completely knowed. The embryo is completely differentiated and mature, indicating that there is no morphological dormancy (Nazário et al., 2013). Ledo et al. (2002) suggest that the delayed and uneven germination is not due to the presence of endocarp.

A dormant seed has no germination capacity over a specific period of time, despite the occurrence of environmental factors that are favorable for germination (Finch-Savage and Leubner-Metzger, 2006). One of the possible causes of seed dormancy is embryonic dormancy. This type of dormancy may be caused by the morphology of underdeveloped embryos associated with a physiological component (mophophisyological dormancy) (Baskin and Baskin, 2014) or by the physiologic response of developed embryos to biochemical and physiologic mechanisms that hamper the occurrence of germination (Bazin et al., 2011).

The failure of embryos to differentiate may be due to immaturity or, in the case of mature embryos, a metabolic impediment to elongation (Borghetti, 2004). The seeds of some species with small embryos complete the morphogenesis phase and possess a totally differentiated embryo in terms of structure but do not undergo maturation. Such seeds always contain relatively large quantities of endosperm that sometimes fully gird a small embryo. In these seeds, embryos grow after scattering for germination, and dormancy is morphologic (Borghetti, 2004; Hilhorst, 2007). However, in other species, the embryo is mature at the moment of dispersion, but physiologic mechanisms result in dormancy of not only caused by the embryo but also by adjacent structures, such as the endosperm.
Some studies have demonstrated that the diverse modalities of physiologic dormancy are a result of the interaction between restrictions caused by structures that gird the embryo and its potential for growth (Duclos et al., 2014; Sánchez et al., 2015; Sharma et al., 2015).

Seed dormancy and its triggers can be investigated using zygotic embryo cultures (Ribeiro et al., 2013; Medeiros et al., 2015). In vitro zygotic embryo culture has been used as an alternative for swift propagation, and among other applications, the method has been used to investigate dormancy caused by embryo immaturity or by the presence of germination inhibitors in the endosperm, in order to study the nutritional and physiologic aspects of embryonic development (Anjun, 2014; Medeiros et al., 2015). Thus, palm embryo culture allows for the assessment of seed physiology, development, and germination (Ribeiro et al., 2012).

The study of zygotic embryo germination is essential for understanding the mechanism of seed dormancy in $B$. gasipaes. Therefore, the aim of this study was to examine embryonic dormancy in peach-palm seeds and its correlation with first cataphyll emergence.

\section{Material and Methods}

The seeds used in this study were obtained from fullgrown fruits (with fruits presenting epicarp completely yellow or red) that were collected from the racemes of eight different plants in 2010. Four of the plants were from a germoplasm bank located at the Instituto Nacional de Pesquisas da Amazônia - INPA (National Institute for Amazonian Research), in Manaus, Amazonas, Brazil, which has an annual average temperature of $27.4{ }^{\circ} \mathrm{C}$ and a average annual rainfall of $2145 \mathrm{~mm}$, and the other four plants cultived were from producers in Coari, Amazonas, Brazil, which has an annual average temperature of $26.3{ }^{\circ} \mathrm{C}$ and an average annual rainfall of $2290 \mathrm{~mm}$ (Climate-data, 2016).

Following all collected pyrenes preparation, which included extraction and seed cleaning, four replications of 25 seeds per plant (totalizing 800 seeds) were sowed in nursery with glass fiber tile cover in a seedbed that was a plastic box with $40 \times 60 \times 10 \mathrm{~cm}$ (width, length and height) with a 1:1 (v:v) mixture of sawdust and sand as substrate. Cleaning was made of rubbing the seeds over a screen in running water and removal of residual waste to the tip of a knife. Concomitantly, the water content of the seeds was determined using a 105 $\pm 3{ }^{\circ} \mathrm{C}$ oven method during 24 hours (Brasil, 2009), with duplicate samples of five seeds.

In order to study the embryo differentiation, an in vitro culture was prepared at the Laboratory of Culture and Vegetal 
Tissues of the University of the Amazonas State. Processed seeds were washed with distilled water and disinfected in accordance with the methods described by Steinmacher et al. (2007). The seeds were disinfected in a laminar flux chamber by immersing them in $70 \%$ alcohol for $5 \mathrm{~min}$, followed by a 40-min immersion in $60 \%$ commercial sodium hypochlorite that contained 1 drop of Tween-20® per $100 \mathrm{~mL}$ of solution as a surfactant, and excess hypochlorite was removed using three rinses with autoclaved water. MS medium (Murashige and Skoog, 1962) with salt half concentration was prepared with the addition of $1.5 \mathrm{~g}$. $\mathrm{L}^{-1}$ activated charcoal, $30 \mathrm{~g}$. L $\mathrm{L}^{-1}$ sucrose, and $7 \mathrm{~g}$. $\mathrm{L}^{-1}$ agar, and by adjusting the $\mathrm{pH}$ to 5.8 before gelling. Culture tubes containing $20 \mathrm{~mL}$ of the MS medium were then closed using aluminum lids, sealed with polyvinyl chloride (PVC) film, and autoclaved for $30 \mathrm{~min}$. Embryos were removed from the seeds in a flux laminar chamber and immediately inoculated into the culture tubes. Ten zygotic embryos (one per tube), per plant, were inoculated with four replicates per plant, totalizing 160 embryos (4X40). The embryo cultures were maintained in a B.O.D. (Biochemical Oxygen Demand) dark chamber at $30{ }^{\circ} \mathrm{C}$ for $60 \mathrm{~d}$ and then transferred to a budding room, where they were exposed to a photoperiod of $16 \mathrm{~h}$ of light at $25 \pm 2{ }^{\circ} \mathrm{C}$ and $52 \mu \mathrm{mol} \mathrm{m}{ }^{-2} \cdot \mathrm{s}^{-1}$ luminosity.

For the assessment of seedbed emergence, the statistic delineation employed completely randomized, with eight treatments (plants) and four replicates with 25 seeds, totalizing 800 seeds. Seed emergence (first cataphyll emergence above the substrate) was evaluated every 5 days (d) for a total of 180 days, and using these data, the percentage emerged, emergence speed index (ESI), and mean emergence time (MET) were calculated. At the end of the evaluation period, residual seeds underwent a cut test (Brasil, 2009) and were classified as dead, dormant, or germinated but not emerged (GNE).

For the assessment of in vitro embryo growth, the statistic delineation employed was completely randomized, with eigth treatments (plants) and four replicates with ten embryos, totalizing 320 embryos. Embryo differentiation was evaluated every seven days for a total of 120 . The differentiation speed index (DSI) and mean differentiation time (MDT), embryo death caused by fungal or bacterial contamination or by oxidation was also recorded, as were swollen embryos without root differentiation. Using these data, the percentages of dead and dormant embryos were calculated.

The data were subjected to the Kolmogorov-Smirnov and Shapiro Wilk tests of normality. Data with a normal distribution were subjected to variable analysis using a $5 \%$ probability level, and Tukey's test was used for comparing the average values for the different source plants. When data did not show a normal distribution, averages were compared using the Kruskal-Wallis test. In addition, for the comparison of averages between the two locations, normally distributed data were analyzed using a $t$-test at a $5 \%$ probability, and non-normally distributed data were analyzed using the Mann Whitney test at a $5 \%$ probability level.

Regression analysis was conducted at a $5 \%$ probability level using the variables recorded for in vitro embryo root differentiation (percentages of differentiated, dead, and dormant embryos; DSI and MDT) and those for the cataphyll emergence of seeds from the same plants (percentages of emerged, dead, and dormant seeds; ESI; and MET). All statistics were performed using Beta ASSISTAT 7.6 (Silva, 2011).

\section{Results and Discussion}

There was no significant difference between the water content of the seeds of Manaus and Coari, with values of $44.54 \%$ and $45.45 \%$, respectively. First cataphyll emergence differed between the seeds from different plants, varying from $16 \%$ to $84 \%$ (Table 1). The percentage of dead seeds at the end of the experiment, after 180 days sowing, also differed significantly between source plants and varied from $10.0 \%$ to $37.0 \%$. The percentage of seeds that remained viable at the end of the experiment (dormant) varied between plants, from $0.0 \%$ to $64.0 \%$. On this occasion, was also observed that some of the seeds had germinated without exhibiting aerial emergence, but there was no difference between seeds from different plants. The ESI varied between seeds from different plants and exhibited a direct relationship with emergence; plants with greater emergence had a greater ESI and viceversa. The MET also varied between the seeds of different plants, with a minimum of $68.4 \mathrm{~d}$ and a maximum of $132.7 \mathrm{~d}$.

A significant difference was observed between the percentage emergence of seeds collected in Manaus $(57.3 \%)$ and those collected in Coari (75.0\%) (Table 2). The percentage of dead seeds did not differ between seeds from the two locations. A significant difference in the percentage of dormant seeds was also observed, with a greater percentage for seeds from Manaus (20.0\%) compared to those from Coari $(5.0 \%)$. There was no difference between localities in the percentage of GNE seeds. The ESI differed between source locations, with average values of 0.145 and 0.231 observed for seeds from Manaus and Coari, respectively, and the MET for seeds collected from Manaus was higher than that for seeds collected from Coari (110 and $92 \mathrm{~d}$, respectively).

In this study, it was verified that the emergence of $B$. gasipaes first cataphylls varies between seeds collected from different plants and locations. Bovi et al. (1994), assessing 83 Yurimáguas progenies from Peru, had previously determined 
Table1. Percentages of emerged, dead, dormant and germinated but not emerged (GNE) seeds; emergence speed index (ESI); and mean emergence time (MET) of Bactris gasipaes seeds.

\begin{tabular}{|c|c|c|c|c|c|c|}
\hline Plant & ${\text { Emerged }(\%)^{1}}^{1}$ & Dead $(\%)^{2}$ & Dormant $(\%)^{1}$ & GNE $(\%)^{1}$ & $\mathrm{ESI}^{2}$ & $\operatorname{MET}_{(\text {days })^{2}}$ \\
\hline $\mathrm{L}_{19 P} 4^{3}$ & $84.0 \mathrm{a}$ & $10.0 \mathrm{a}$ & $4.0 \mathrm{~b}$ & $2.0 \mathrm{a}$ & $0.201 \mathrm{bc}$ & $108.4 \mathrm{~d}$ \\
\hline $\mathrm{L} 11 \mathrm{P} 3^{3}$ & $67.0 \mathrm{bc}$ & $20.0 \mathrm{ab}$ & $12.0 \mathrm{c}$ & $1.0 \mathrm{a}$ & $0.155 \mathrm{c}$ & $110.9 \mathrm{~d}$ \\
\hline $\mathrm{L}^{18 \mathrm{P}} 3^{3}$ & $16.0 \mathrm{e}$ & 17. $0 \mathrm{ab}$ & $64.0 \mathrm{~d}$ & $3.0 \mathrm{a}$ & $0.032 \mathrm{~d}$ & $132.7 \mathrm{e}$ \\
\hline $\mathrm{L} 15 \mathrm{P} 5^{3}$ & $62.0 \mathrm{~d}$ & $37.0 \mathrm{~b}$ & $0.0 \mathrm{a}$ & $1.0 \mathrm{a}$ & $0.190 \mathrm{bc}$ & $88.7 \mathrm{bc}$ \\
\hline$A^{4}$ & $82.0 \mathrm{a}$ & $16.0 \mathrm{ab}$ & $1.0 \mathrm{a}$ & $1.0 \mathrm{a}$ & $0.328 \mathrm{a}$ & $68.4 \mathrm{a}$ \\
\hline $\mathrm{B}^{4}$ & $64.0 \mathrm{~cd}$ & $20.0 \mathrm{ab}$ & $13.0 \mathrm{c}$ & $3.0 \mathrm{a}$ & $0.157 \mathrm{c}$ & $104.4 \mathrm{~cd}$ \\
\hline $\mathrm{C}^{4}$ & $70.0 \mathrm{bc}$ & $10.0 \mathrm{a}$ & $6.0 \mathrm{~b}$ & $14.0 \mathrm{a}$ & $0.164 \mathrm{bc}$ & $112.4 \mathrm{~d}$ \\
\hline$D^{4}$ & $84.0 \mathrm{a}$ & $15.0 \mathrm{ab}$ & $0.0 \mathrm{a}$ & $1.0 \mathrm{a}$ & $0.274 \mathrm{ab}$ & $80.9 \mathrm{ab}$ \\
\hline $\mathrm{CV}^{5}(\%)$ & 21.52 & 59.47 & 43.57 & 163.78 & 26.16 & 20.32 \\
\hline
\end{tabular}

Means of four replicates of 25 seeds each replication.

Same letters in columns are not statistically different at $5 \%$ probability $(\mathrm{p}<0.05)$ by ${ }^{1}$ Kruskal-Wallis and ${ }^{2}$ Tukey's tests.

${ }^{3}$ Seeds collected in Manaus.

${ }^{4}$ Seeds collected in Coari.

${ }^{5} \mathrm{CV}=$ Coefficient of variation.

that seed germination of this species varied from $0 \%$ to $100 \%$, with the majority of progenies exhibiting a germination rate between $60.0 \%$ and $89.9 \%$. This percentage was confirmed in the current study. Bovi et al. (1994) also found that germination speed index varied from 0.00 to 2.55 and that mean germination time varied from 38 to $133 \mathrm{~d}$. Regarding the progenies examined in the current study, the DSI and MDT showed great variation but remained near the range reported by Bovi et al. (1994).

Palm seeds show great variation in germination between maturation, progenies and localities (Pimenta et al., 2010). In this study were utilized just bunches with fruits presenting epicarp completely yellow or red, for all progenies,indicating just seeds completely mature. Martins-Corder and Saldanha (2006) showed that Euterpe edulis Mart. seeds from different progenies exhibited variation in germination, from $14 \%$ to $56 \%$. In addition, Elaeis guineensis Jacq. seeds from different progenies under the same pre-germination treatment exhibited the same variation, from $5.0 \%$ to $85.9 \%$ (Fondom et al., 2010). Furthermore, for E. edulis and Syagrus romanzoffiana (Cham.) Bracalion et al. (2011) indicated that germination and speed of germination varied significantly between areas of collection. B. gasipaes is a species of domesticated palm, but historically, the matrix plant selection for seed collection and propagation has always been associated with the methods used by the local population, such that cultivated progenies in different regions have distinct phenotypic characteristics, such as germination capacity and seed dormancy (Clement, 2008).

Differences in embryo root differentiation related to the source location were not observed (Table 3 ). The percentage of dormant embryos differed between localities, with an average of $11.3 \%$ for Manaus and $3.1 \%$ for Coari. A difference in DSI
Table 2. Percentages of emerged, dead, dormant, and germinated but not emerged (GNE) seeds; emergence speed index (ESI); and mean emergence time (MET) of Bactris gasipaes seeds from fruits collected in Manaus and Coari, Amazonas, Brazil.

\begin{tabular}{lrr}
\hline \multirow{2}{*}{ Seeds } & \multicolumn{2}{c}{ Origin } \\
\cline { 2 - 3 } & Manaus & Coari \\
\hline Emerged $(\%)^{1}$ & $57.3 \mathrm{~b}$ & $75.0 \mathrm{a}$ \\
Dead $(\%)^{2}$ & $21.0 \mathrm{a}$ & $15.3 \mathrm{a}$ \\
Dormant $(\%)^{1}$ & $20.0 \mathrm{~b}$ & $5.0 \mathrm{a}$ \\
${\text { GNE }(\%)^{1}}^{\text {ESI }^{2}}$ & $1.8 \mathrm{a}$ & $4.8 \mathrm{a}$ \\
MET $\left(\right.$ days $^{2}$ & $0.145 \mathrm{~b}$ & $0.231 \mathrm{a}$ \\
\hline
\end{tabular}

Same letters in rows are not statistically different at $5 \%$ probability $(\mathrm{p}<0.05)$ by ${ }^{1}$ Kruskal-Wallis and ${ }^{2}$ Tukey's tests.

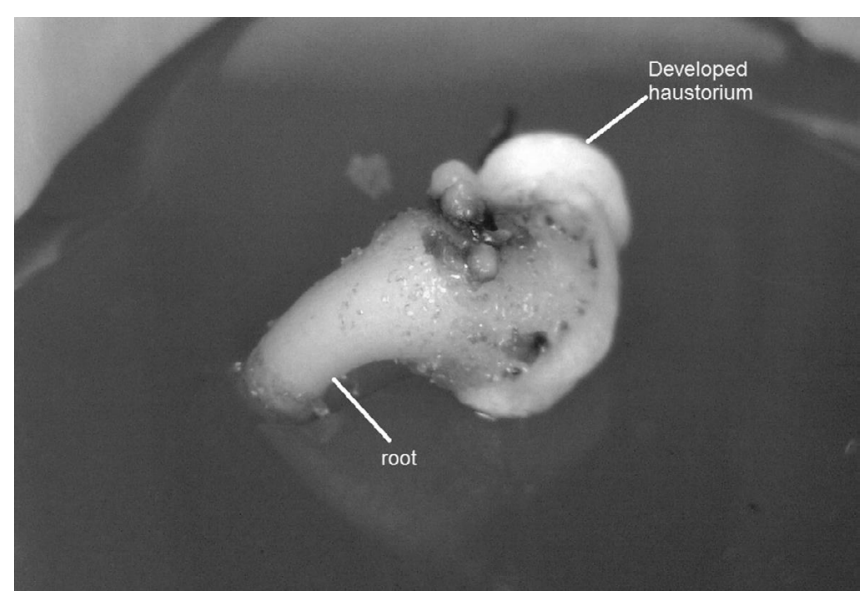

Figure 1. Zygotic embryo of Bactris gasipaes from in vitro culture showing root emergence. 
Table 3. Percentages of differentiated, dead, and dormant embryos; differentiation speed index (DSI); and mean differentiation time (MDT) of B. gasipaes embryos from fruits collected in Manaus and Coari, Amazonas, Brazil.

\begin{tabular}{lcc}
\hline \multirow{2}{*}{ Embryo } & \multicolumn{2}{c}{ Origin } \\
\cline { 2 - 3 } & Manaus & Coari \\
\hline Differentiated $(\%)^{1}$ & $73.1 \mathrm{a}$ & $87.5 \mathrm{a}$ \\
${\text { Dead }(\%)^{1}}^{*} 15.6 \mathrm{a}$ & $9.4 \mathrm{a}$ \\
${\text { Dormant }(\%)^{1}}$ & $11.3 \mathrm{~b}$ & $3.1 \mathrm{a}$ \\
DSI $^{2}$ & - & - \\
MDT (days) $^{1}$ & $0.202 \mathrm{~b}$ & $0.269 \mathrm{a}$ \\
\hline
\end{tabular}

Same letters in rows are not statistically different at $5 \%$ probability $(\mathrm{p}<0.05)$ by ${ }^{~}$ Kruskal-Wallis and ${ }^{2}$ Tukey's tests.

was seen for seeds collected in Manaus (0.202) and those collected in Coari (0.269). A difference in the MDT between localities was not observed.

Embryo axle differentiation (primary root emergence - Figure 1) did not differ between the embryos from different source plants, exhibiting a minimum of $37.5 \%$ and a maximum of $92.5 \%$ (Table 4), nor did the percentage of dead embryos (oxidized and contaminated) between source plants or locations.

The percentage of embryos that remained viable, dormant and without oxidation differed between source plants, with a minimum of $0 \%$ and a maximum of $30 \%$. The DSI differed between source plants, varying from 0.136 to 0.323 , while the MDT of embryo root differentiation did not.

The in vitro cultivation of palm zygotic embryos has been shown to result in germination in less time than that required for germination from seed (Magalhães et al., 2013; Pádua et al., 2014). However, in this study, great variation in embryonic dormancy was observed between embryos from different plants of the same source such that dormancy appears to vary depending on the mother plant. The variation in dormancy of seeds of different plants is known in the literature (Bovi et al., 1994). Some species presents seeds with small embryosthat complete the morphogenesis phase and possess a totally differentiated embryo in terms of structure but do not undergo maturation. Such seeds always contain relatively large quantities of endosperm that sometimes fully gird a small embryo. In these seeds, embryos grow after scattering for germination, and dormancy is morphologic (Borghetti, 2004; Hilhorst, 2007). In other species, the embryo is mature at the moment of dispersion, but physiologic mechanisms result in dormancy of not only caused by the embryo but also by adjacent structures, such as the endosperm. Recent studies have demonstrated that the diverse modalities of physiologic dormancy are a result of the interaction between restrictions caused by structures that gird the embryo and its potential for growth (Duclos et al., 2014; Sánchez et al., 2015; Sharma et al., 2015). In Elaeis guineensis seeds, Norsazwan et al. (2016) verified a combination of both morphological and physical dormancy. Dormancy of mature embryos may be the result of an impediment caused by the cotyledons in the embryonic axle in both structures (Borghetti, 2004).

Regression analysis of in vitro embryo differentiation and first cataphyll emergence in the seedbed revealed a significant association $(\mathrm{p}<0.05)$, and the ESI of first cataphyll from seeds showed a linear relationship $\left(\mathrm{R}^{2}=0.66\right)$ with the DSI of in vitro embryos (Figure 2-A). The estimated ESI varied from 0.062 when DSI was 0.136 to 0.299 when DSI was 0.323 . In addition, the relationship between the MDT of in vitro embryos and the MET of seeds was linear, with a coefficient of determination

Table 4. Percentages of differentiated, dead, and dormant embryos; differentiation speed index (DSI); and mean differentiation time (MDT) for embryos of Bactris gasipaes.

\begin{tabular}{|c|c|c|c|c|c|}
\hline Plant & Differentiated $(\%)^{1}$ & Dead $(\%)^{1}$ & 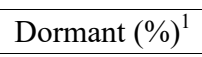 & $\mathrm{DSI}^{2}$ & MDT (days) $^{1}$ \\
\hline $\mathrm{L}_{19 P}{ }^{3}$ & $85.0 \mathrm{a}$ & $10.0 \mathrm{a}$ & $5.0 \mathrm{c}$ & $0.194 \mathrm{bc}$ & $42.3 \mathrm{a}$ \\
\hline $\mathrm{L} 11 \mathrm{P} 3^{3}$ & $87.5 \mathrm{a}$ & $7.5 \mathrm{a}$ & $5.0 \mathrm{c}$ & $0.216 b c$ & $43.7 \mathrm{a}$ \\
\hline $\mathrm{L}_{18 \mathrm{P}} 3^{3}$ & $37.5 \mathrm{a}$ & $32.5 \mathrm{a}$ & $30.0 \mathrm{~d}$ & $0.136 \mathrm{c}$ & $49.5 \mathrm{a}$ \\
\hline $\mathrm{L}_{15} \mathrm{P}^{3}$ & $82.5 \mathrm{a}$ & $12.5 \mathrm{a}$ & $5.0 \mathrm{c}$ & $0.263 \mathrm{ab}$ & $31.8 \mathrm{a}$ \\
\hline$A^{4}$ & $92.5 \mathrm{a}$ & $2.5 \mathrm{a}$ & $5.0 \mathrm{c}$ & $0.323 \mathrm{a}$ & $25.6 \mathrm{a}$ \\
\hline$B^{4}$ & $87.5 \mathrm{a}$ & $10.0 \mathrm{a}$ & $2.5 \mathrm{~b}$ & $0.275 \mathrm{ab}$ & $31.0 \mathrm{a}$ \\
\hline $\mathrm{C}^{4}$ & $82.5 \mathrm{a}$ & $12.5 \mathrm{a}$ & $5.0 \mathrm{c}$ & $0.225 \mathrm{abc}$ & $28.5 \mathrm{a}$ \\
\hline $\mathrm{D}^{4}$ & $87.5 \mathrm{a}$ & $12.5 \mathrm{a}$ & $0.0 \mathrm{a}$ & $0.251 \mathrm{ab}$ & $29.3 \mathrm{a}$ \\
\hline $\mathrm{CV}(\%)^{5}$ & 12.52 & 66.33 & 97.35 & 19.39 & 82.85 \\
\hline
\end{tabular}

Means of four replicates of 25 seeds each replication.

Same letters in columns are not statistically different at $5 \%$ probability $(\mathrm{p}<0.05)$ by ${ }^{1}$ Kruskal-Wallis and ${ }^{2}$ Tukey's tests.

${ }^{3}$ Seeds collected in Manaus.

${ }^{4}$ Seeds collected in Coari.

${ }^{5} \mathrm{CV}=$ Coefficient ${ }^{4}$ Coefficient of variation. 
of 0.61 (Figure 2-B). In seeds whose embryos had an MDT of $25.6 \mathrm{~d}$, the MET was $83.2 \mathrm{~d}$, whereas the MET reached 127.0 $\mathrm{d}$ for seeds whose embryos had an MDT of 49.5 days. This is probably due to presence of embryo dormancy, it reveals that the time required for seedling emergence from seeds, is directly related to the time required to vary the embryos. Nazario et al. (2013) observed plumule presence that contains three foliar primordial; indicating that, on the moment of dispersal, the embryo is fully differentiated and mature, thus eliminating the possibility of morphological dormancy in these seeds. The cells in the protrusion region of the seed contain acidic lipids, proteins, and neutral polysaccharides. These results indicates that most likely Bactris gasipaes seeds have physiological dormancy, probably deep type, because in non deep physiological dormancy embryos excised produce normal seedlings (Baskin and Baskin, 2004). The hormonal mechanisms involved in palm seed dormancy are not fully understood. However, according with Baskin and Baskin (2014) would be expected that abscisic acid play a role in palm diaspore dormancy by inhibiting the growth potential of the embryo and by weakening of the endosperm cap.

However, at the end of the experiment, the percentage of dead seeds was not significantly related to the percentage of dead embryos, which was $18.1 \%$ on average. The percentage of seeds that remained dormant was not significantly associated with the percentage of dormant embryos, either.

In this study, a high percentage of embryo differentiation was observed, without their seedling emergence. The mean differentiation time (MDT) was $35.2 \mathrm{~d}$, whereas the mean MET was 100.9 (Figure 2B). Simillar results were found in Bactris major Jacq. embryos, when isolated and cultivated in vitro, initiate differentiation within $10 \mathrm{~d}$, and intact $B$. major seeds begin to differentiate after eight months. In Desmoncus orthacanthus Mart., the initial germination time of two months using intact seeds was reduced to $2 \mathrm{~d}$ using embryo culture (Tzec-Simá et al., 2006). These results suggest that in $B$. gasipaes occurs dormancy (attached to the seed coat or endosperm), as well as B. major and Desmoncus orthacanthus. However, in B. gasipaes embryo dormancy is present as germination was slow even in isolated embryos, which strengthens the indication of deep physiological dormancy (Baskin and Baskin, 2014).

The development of full embryo buds was not observed during the $120 \mathrm{~d}$ of observation. This finding may have been the result of the reduced concentration of MS medium used in the culture, which is sufficient for root differentiation but insufficient for bud formation. In some species, such as Cocos nucifera Linn. it is even necessary to transfer the differentiated embryos to a fresh culture in order to achieve bud development (Engelmann et al., 2011).

It is possible to affirm that seed dormancy is caused, in part, by embryonic dormancy because seeds with slow germination also exhibit slow embryonic differentiation (Figure 2), demonstrated by the significant correlation between the emergence speed index and the index of differentiation speed. Embryonic dormancy is a known process in palm species, but not to all. Ribeiro et al. (2011) studied dormancy in Acrocomia aculeata (Jacq.) Lodd. ex Mart. and showed that the seeds exhibited physiologic dormancy associated with the embryo. However, and Dewir et al. (2011) demonstrated that seeds of Sabal palmetto Walt. exhibit both exogenous and physiologic dormancy, whereas dormancy in the seeds of Thrinax morrisii $\mathrm{H}$. Wendl was fully controlled by the testa. Ribeiro et al. (2013) verified that in Acrocomia aculeata the germination of isolated embryos was $87 \%$, while only $14 \%$ of the embryos in contact with endosperm and operculum germinated and concluded that dormancy is related to failure of the embryo to overcome the resistance of the adjacent tissues.
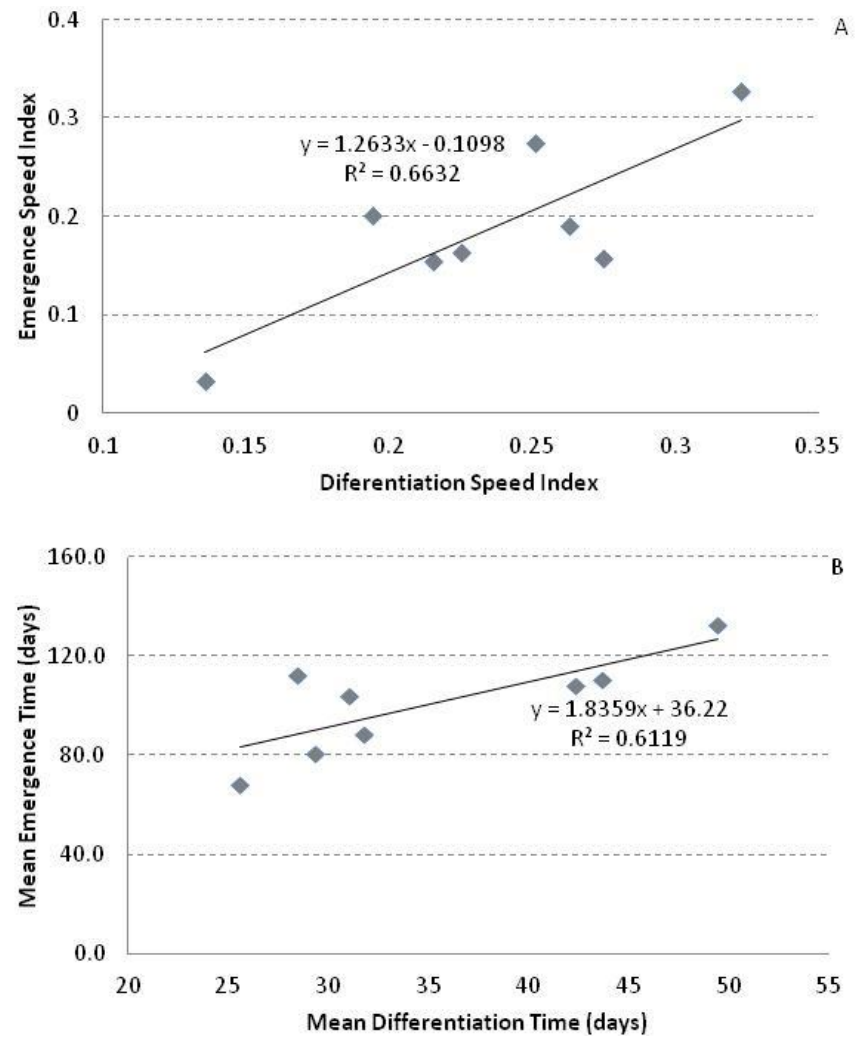

Figure 2. Seedling emergence speed index as a function of embryo differentiation speed index (A) and mean seedling emergence time as a function of mean embryo differentiation time (B) for seeds of Bactris gasipaes. 
In $A$. aculeata seed, germination involves reductions in ABA content and, consequently, increased GA/ABA in the embryo (Bicalho et al., 2015).

In this study is suggested that Bactris gasipaes have physiologic dormancy. There are several ways of physiologic dormancy, that can be a result of the interaction between restrictions caused by structures that gird the embryo and its potential for growth (Sánchez et al., 2015; Sharma et al., 2015), according was observed in present study.

\section{Conclusions}

Seedling emergence and germination of Bactris gasipaes embryos are positively correlated suggesting that, at least in part, seed dormancy is associated with embryonic dormancy.

\section{Acknowledgments}

We are grateful to Coordenação de Aperfeiçoamento de Pessoal de Nível Superior (CAPES) for supporting this research and to Dr. Angela Maria Imakawa for precious help during the conduction of this research.

\section{References}

ANJUN, T.A.N.G. In vitro embryo culture of rarely endangered Musella lasiocarpa (musaceae) with embryo dormancy. Pakistan Journal of Botany, v.46, n.6, p.2173-2177, 2014. http://www.pakbs. org/pjbot/PDFs/46(6)/34.pdf

BARBOSA-RODRIGUES, J. As nupcias das palmeiras (primeiras notas) [The nuptials of palm trees (first notes)]. In: BARBOSARODRIGUES, J. (ed). Palmae Novae Paraguayensis quas Descripsit et Iconibus Illustravit. Typographia Leuzinger, Rio de Janeiro, Brasil, p.35-51, 1899.

BASKIN, J.M.; BASKIN, C.C. A classification system for seed dormancy. Seed Science Research, v.14, p.1-16, 2004. https://www. cambridge.org/core/services/aop-cambridge-core/content/view/ S0960258504000017

BASKIN, J.M.; BASKIN, C.C. What kind of seed dormancy might palms have? Seed Science Research, v.24, n.01, p.17-22, 2014. $\mathrm{http}$ ://journals.cambridge.org/action/displayAbstract?fromPage $=$ online\&aid $=9174540 \&$ fileId $=$ S0960258513000342

BAZIN, J.; BATLLA, D.; DUSSERT, S.; EL-MAAROUF-BOUTEAU, H.; BAILLY, C. Role of relative humidity, temperature, and water status in dormancy alleviation of sunflower seeds during dry after-ripening. Journal of Experimental Botany v.62, p.627-640, 2011. http://jxb. oxfordjournals.org/content/early/2010/10/26/jxb.erq314.short
BICALHO, E. M.; PINTÓ-MARIJUAN, M.; MORALES, M.; MÜLLER, M.; MUNNÉ-BOSCH, S.; GARCIA, Q. S. Control of macaw palm seed germination by the gibberellin/abscisic acid balance. Plant Biology Journal, v.17, p.990-996, 2015. http:// onlinelibrary.wiley.com/doi/10.1111/plb.12332/pdf

BORGHETTI, F. Dormência embrionária [Embryo dormancy]. In: FERREIRA, A.G.; BORGHETTI, F. (eds). Germinação: do básico ao aplicado. Artmed, Porto Alegre, Brasil, 2004. p.109-123.

BOVI, M.L.A.; SPIERING, S.H.; MARTINS, A.L.D.; PIZZINATO, M.A.; LOURENÇÃO, A.L.; CHAVES FLORES, W.B. Seed germination of progênies of Bactris gasipaes: percentage, speed and duration. Acta Horticulturae, v. 360, p.283-289, 1994.

BRACALION, P.H.S.; NOVEMBRE, A.D.L.C.; RODRIGUES, R.R. Seed development, yield and quality of two palm species growing in different tropical forest types in SE Brazil: implications for ecological restoration. Seed Science and Technology, n.39, p.412-424, 2011. http://www.ingentaconnect.com/content/ista/ sst/2011/00000039/00000002/art00013

BRASIL. Ministério da Agricultura, Pecuária e Abastecimento. Regras para análise de sementes. Ministério da Agricultura, Pecuária e Abastecimento. Secretaria de Defesa Agropecuária. Brasília: MAPA/ACS, 2009. 395p. http://www.agricultura.gov.br/arq editor/ file/2946_regras_analise_sementes.pdf

CLEMENT, C.R. Peach palm (Bactris gasipaes Kunth, Palmae). In: JANICK, J.; PAULL, R.E.(eds). The encyclopedia of fruit and nuts. CABI, London, United Kingdom. p.93-101. 2008.

CLIMATE-DATA. Clima:Amazonas. http://pt.climate-data.org/ region/95/ Accessed on: Sep 19 , $^{\text {th }} 2016$.

DEWIR, Y.H.; EL-MAHROUK, M.E.; NAIDOO, Y. Effects of some mechanical and chemical treatments on seed germination of Sabal palmetto and Thrinax morrisii palms. Australian Journal of Crop Science, v.5, n.3, p.248-253, 2011. http://search.proquest.com/open view/3969178bcf5b927de603c8deb44e4c02/1?pq-origsite=gscholar

DUCLOS, D.V.; ALTOBELLO, C.O.; TAYLOR, A.G. Investigating seed dormancy in switchgrass (Panicum virgatum L.): Elucidating the effect of temperature regimes and plant hormones on embryo dormancy. Industrial Crops and Products, v.58, p.148159, 2014. http://www.sciencedirect.com/science/article/pii/ S0926669014002143

ENGELMANN, F.; MALAURIE, B.; N'NAN, O. In vitro culture of coconut (Cocos nucifera L.). In: THORPE, T.A.; YEUNG, E.C. (eds). Plant embryo culture: methods and protocols. Calgary, Alberta, Canada, 2011. p. 63-74.

FINCH-SAVAGE， W.E.; LEUBNER-METZGER， G. Seed dormancy and the control of germination. New Phytologist, v.171, p.501-523, 2006. http://onlinelibrary.wiley.com/doi/10.1111/j.14698137.2006.01787.x/full

FONDOM, N.Y.; ETTA, C.E.; MIH, A.M. Breaking seed dormancy: revisiting heat-treatment duration on germination and subsequent seedling growth of oil palm (Elaeis guineensis Jacq.) progenies. Journal of Agricultural Science, n.1, p.51-58, 2010. http://www. ccsenet.org/journal/index.php/jas/article/download/4402/4927 
GOULDING, M.; SMITH, N. Palmeiras: Sentinelas para a conservação da Amazônia [Palms: Sentinels for Amazon conservation]. Amazon Conservation Association- Sociedade Civil Mamirauá, Lima, Peru. 2007. 358 p.

HILHORST, H.W.M. Definitions and hypotheses of seed dormancy. Annual Plant Reviews: Seed development, dormancy, and germination, v.27, p.50-71, 2007. http://onlinelibrary.wiley.com/ doi/10.1002/9780470988848.ch3/

LEDO, A.S; MEDEIROS FILHO, S.; LEDO, F.J.S.; ARAÚJO, E.C. Efeito do tamanho da semente, do substrato e pré-tratamento na germinação das sementes de pupunha. Ciência Agronômica, v.33, n.1, p.29-32, 2002. http://ainfo.cnptia.embrapa.br/digital/bitstream/ item/115634/1/17387.pdf

MAGALHÃES, H.M.; LOPES, P.S.N.; RIBEIRO, L.M.; SANT'ANNA-SANTOS, B.F.; OLIVEIRA, D.M. Structure of the zygotic embryos and seedlings of Butia capitata (Arecaceae). Trees, v.27, n.1, p.273-283, 2013. http://link.springer.com/article/10.1007/ s00468-012-0797-1

MARTINS-CORDER, M.P.; SALDANHA, C.W. Germinação de sementes e crescimento de plântulas de diferentes progênies de Euterpe edulis Mart [Seed germination and seedling growth of different progenies of Euterpe edulis Mart]. Revista Arvore, v.30, n.5, p.693-699, 2006. http://www.sidalc.net/cgibin/wxis.exe/?IsisScript $=$ SCBR .xis \&method $=$ post $\&$ formato $=2 \&$ cantidad $=1 \&$ expresion $=\mathrm{mfn}=025911$

MEDEIROS, M.J.; OLIVEIRA, D.S.; OLIVEIRA, M.T.; WILLADINO, L.; HOULLOU, L.; SANTOS, M.G. Ecophysiological, anatomical and biochemical aspects of in vitro culture of zygotic Syagrus coronata embryos and of young plants under drought stress. Trees, v.29, n.4, p.1219-1233, 2015. http://link.springer.com/article/10.1007/s00468015-1202-7\#/page-1

MORA-URPÍ, J. Método practico para germinación de semillas de pejibaye [Practical method for germination of peach palm]. Asbana, v. 3 , p. $14-15,1979$.

MURASHIGE, T; SKOOG, F. A revised medium for rapid growth and bioassays with tobacco tissue cultures. Physiologia Plantarum, v. 15, p. $473-497,1962$.

NAZÁRIO, P.; FERREIRA, S.A.N.; BORGES, E.E.L.; GENOVESEMARCOMINI, P.R.; MENDONÇA, M. S. Anatomical and histochemical aspects of the peach palm (Bactris gasipaes Kunth) seed. Journal of Seed Science, v.35, n.2, p.171-178, 2013. http://www.scielo.br/scielo. php?script=sci_arttext\&pid=S2317-15372013000200005

NORSAZWAN, M.G.; PUTEH, A.B.; RAFII, M.Y. Oil palm (Elaeis guineensis) seed dormancy type and germination pattern. Seed Science and Technology, v.44, n.1, p.15-26, 2016. http://www.ingentaconnect. com/content/ista/sst/2016/00000044/00000001/art00002

PÁDUA, M.S.S.; PAIVA, L.V.; SILVA, L.G.T.; SILVA, L.C.; STEIN, V.C. In vitro development and acclimatization of dendezeiro (Elaeis guineensis). Revista Árvore, v.38, n.6, p.1095-1102, 2014. http://www. scielo.br/scielo.php?pid=S0100-67622014000600014\&script=sci_arttext
PIMENTA, R.S.; LUZ, P. B.; PIVETTA, K.F.L.; CASTRO, A.; PIZETTA, P.U. Efeito da maturação e temperatura na germinação de sementes de Phoenix canariensis hort. ex Chabaud - Arecaceae. Revista Árvore, v.34, n.1, p.31-38, 2010. http://www.scielo.br/pdf/ rarv/v34n1/v34n1a04.pdf

RIBEIRAL, R. Avança consumo de palmito cultivado. Inaceres cultivando saúde, 30 abr. 2011. http://www.inaceres.com.br/detalhe noticias.php?recordID=84 .Accessed on: Sep $6^{\text {th }}, 2016$.

RIBEIRO, L.M.; SOUZA, P.P.; RODRIGUES JR.;A.G.; OLIVEIRA, T.G.S.; GARCIA, Q.S. Overcoming dormancy in macaw palm diaspores, a tropical species with potential for use as bio-fuel. Seed Science and Technology, v. 39, n.2, p.303-317, 2011. http://www. ingentaconnect.com/content/ista/sst/2011/00000039/00000002/ art00004

RIBEIRO, L.M.; OLIVEIRA, D.M.T.; GARCIA, Q.S. Structural evaluations of zygotic embryos and seedlings of the macaw palm (Acrocomia aculeata, Arecaceae) during in vitro germination. Trees, v.26, n.3, p.851-863, 2012. http://link.springer.com/article/10.1007/ s00468-011-0659-2

RIBEIRO, L.M.; SILVA, P.O.; ANDRADE, I.G.; GARCIA, Q.S. Interaction between embryo and adjacent tissues determines the dormancy in macaw palm seeds. Seed Science and Technology, v.41, n.3, p.345-356, 2013. http://www.ingentaconnect.com/content/ista/ sst/2013/00000041/00000003/art00003

SÁNCHEZ, J.A.; MONTEJO, L.; GAMBOA, A.; ALBERT-PUENTES, D.; HERNÁNDEZ, F. Germination and dormancy of shrubs and climbing plants of the evergreen forest of Sierra del Rosario, Cuba. Pastures and Forages, v.28, n.1, p.11-28, 2015. http://pastures-forages.ihatuey.cu/ index.php/Pastures_Forages/article/view/274

SILVA, F.A.S. Assistat. Versão 7.6. Beta. www.assistat.com. Accessed on: Aug 12 $2^{\text {th }}$, 2011. UAEA-CTRN-UFCG, Campina Grande, Brasil, 2011.

SHARMA, B.D.; SINGH, L.; KAUR, M.J. Seed biology, dormancy and phenophases of seed germination of three rare Himalayan herbs. Journal of Non-Timber Forest Products, v.22, n.3, p.143-147, 2015. http://www.hrg.org.in/upload/Ashtvarga-Paper.pdf

STEINMACHER, D. A.; CANGAHUALA-INOCENTE.; G. C.; CLEMENT, C. R.; GUERRA, M. P. Somatic embryogenesis from peach palm zygotic embryos. In Vitro Cellular \& Developmental Biology-Plant, v.43, v.2, p.124-132, 2007. http://link.springer.com/ article/10.1007/s11627-007-9032-y

THE PLANT LIST. Version 1.1. 2013. http://www.theplantlist.org/. Accessed on: Sep 6 ${ }^{\text {th }}, 2016$.

TZEC-SIMÁ, M.A.; ORELLANA, R.; ROBERT, M.L. In vitro rescue of isolated embryos of Bactris major Jacq. and Desmoncus orthacanthos Mart., potentially useful native palms from the Yucatan Peninsula (Mexico). In Vitro Cellular \& Developmental Biology-Plant, v.42, p.54 58, 2006. http://link.springer.com/article/10.1079/IVP2005715 